\title{
Rancang Bangun Pendingin Susu Hasil Pasteurisasi Menggunakan Metode Water Cooling System
}

\author{
Gita Adi ${ }^{1}$ Harianto ${ }^{2}$ Yosefine Triwidyastuti ${ }^{3}$ \\ Program Studi/Jurusan Teknik Komputer Institut Bisnis dan Informatika Stikom Surabaya \\ Email: 1.gitaadip@gmail.com, ${ }^{2}$ hari@stikom.edu, ${ }^{3}$ yosefine@stikom.edu
}

\begin{abstract}
Abstrak: Berdasarkan SNI 01-3951-1995, untuk melakukan proses pasteurisasi susu harus mengalami pemanasan di suhu $63^{\circ} \mathrm{C}-66^{\circ} \mathrm{C}$ selama minimum 30 menit atau di suhu $72^{\circ} \mathrm{C}$ selama 15 detik. Namun penelitian yang telah ada menghasilkan sistem pasteurisasi susu yang tidak memiliki sistem pendinginan yang terpadu. Proses pendinginan susu masih dilakukan dengan cara manual (dibiarkan terbuka pada suhu ruangan). Penulis memiliki gagasan untuk membuat suatu alat pendingin susu menggunakan metode water cooling system yang dapat bekerja secara otomatis. Pendingin ini mampu mempercepat proses pendinginan susu dan mengurangi campur tangan manusia. Dari hasil percobaan, didapatkan data waktu yang dibutuhkan untuk proses pendinginan susu sampai sesuai dengan suhu ruangan $32.5^{\circ} \mathrm{C}$ dan tanpa perlakuan apapun adalah 7 jam 20 menit. Sedangkan durasi rata-rata waktu pendinginan menggunakan alat yang dibuat adalah 1 jam 25 menit.
\end{abstract}

Kata Kunci: Susu Pasteurisasi, Proses Pendinginan Susu, Sensor Suhu DS18B20, Water Cooling System, Kontroler PID

\begin{abstract}
Based on SNI 01-3951-1995, in the pasteurization process milk must be boiled at a temperature of $63^{\circ} \mathrm{C}-66^{\circ} \mathrm{C}$ for a minimum of 30 minutes or at a temperature of $72^{\circ} \mathrm{C}$ for 15 seconds. However, existing research has produced a milk pasteurization system that does not have an integrated cooling system. The milk cooling process is still done manually (left open at room temperature). The author has the idea to make a milk cooling device using the water cooling system that can work automatically. This cooler can accelerate the process of cooling milk and reduce human intervention. From the results of the experiment, data obtained from the time needed for the milk cooling process to reach the room temperature of $32.5^{\circ} \mathrm{C}$ and without any treatment is 7 hours 20 minutes. While the average duration of cooling time using the automatic tool is 1 hour 25 minutes.
\end{abstract}

Keywords: Pasteurization Milk, Milk Cooling Process, DS18B20 Temperature Sensor, Water Cooling System, PID Controller

\section{PENDAHULUAN}

Semakin hari perkembangan teknologi informasi dan elektronik melaju semakin pesat. Menurut Soesatyo pada artikel detik.com [1] mesin tenaga uap mengawali Revolusi Industri Pertama.. Kemudian Revolusi Industri Kedua ditandai dengan adanya tenaga listrik yang memungkinkan proses produksi lebih mudah dan banyak dalam waktu singkat. Revolusi Industri Ketiga muncul karena didukung teknologi informasi dan elektronik industri. Perubahan otomatisasi produksi mendorong munculnya jenis pekerjaan pada bidang baru. Otomatisasi industri adalah salah satu cara yang digunakan oleh pelaku industri untuk memperkecil biaya produksi dan meningkatkan kualitas serta kuantitas produksi.

Susu adalah salah satu bahan pangan penting yang mengandung banyak zat gizi. Susu merupakan elemen penting penyeimbang program 4 Sehat 5 Sempurna yang sudah dipopulerkan sejak tahun 1950. Terdapat banyak nutrisi penting pada susu yaitu protein, karbohidrat, kalori, lemak, kalsium, fosfor, zat besi, vitamin, dan air. Pada kehidupan sehari- 
hari masyarakat modern saat ini susu maupun produk olahan susu sangat mudah ditemukan.

Berdasarkan SNI 01-3951-1995, untuk melakukan proses pasteurisasi agar susu siap dikonsumsi susu harus mengalami pemanasan di suhu $63^{\circ} \mathrm{C}-66^{\circ} \mathrm{C}$ selama minimum 30 menit atau di suhu $72^{\circ} \mathrm{C}$ selama 15 detik. Pada penelitian sebelumnya [2] yang berjudul Kendali Temperatur Menggunakan PID Untuk Sistem Pasteurisasi Susu dan yang berjudul Kendali Suhu Menggunakan Fuzzy Logic Untuk Sistem Pasteurisasi Susu [3] tidak memiliki sistem pendinginan susu yang terpadu. Proses pendinginan susu masih dilakukan dengan cara manual (dibiarkan terbuka pada suhu ruangan). Penulis memiliki gagasan untuk membuat suatu alat agar mengurangi campur tangan manusia dalam proses penurunan suhu susu hasil pasteurisasi sebelum pengemasan. Alat pendingin susu hasil pasteurisasi ini diharapkan mampu mempercepat proses pengolahan susu dan dapat dilakukan secara otomatis.

\section{Susu Segar}

Pada Gambar 1, susu adalah air susu hasil pemerahan yang tidak mengurangi atau ditambahkan bahan apapun yang diperoleh dari pemerahan sapi yang sehat. Susu merupakan minuman yang disukai banyak manusia karena mengandung banyak zat gizi, mudah dicerna.

Susu mengandung banyak sekali protein yang bermutu tinggi dengan kadar lemak 3,0 sampai 3,8 \%. Susu ini merupakan sumber kalsium dan fosfat yang baik, tinggi kandungan vitamin A, thiamin, niacin, dan riboflavin.

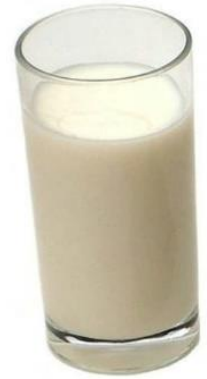

Gambar 1. Segelas Susu Segar

\section{Pasteurisasi Susu}

Pasteurisasi bertujuan untuk mengurangi jumlah mikroorganisme yang dapat menimbulkan penyakit pada manusia misalnya Coxiella bunetti atau Mycobacterium tuberculosis [4]. Proses tersebut juga dapat mematikan enzim katalase dan fosfatase yang membuat susu cepat rusak. Proses pasteurisasi diharapkan bisa membunuh $99 \%$ dari mikroorganisme yang berbahaya dan membuat daya simpan susu menjadi lebih lama. Ada 3 metode pasteurisasi yaitu:

1. Pasteurisasi HTST (High Temperature Short Time) ialah pemanasan susu selama rentang waktu 15-16 detik di suhu 71,7 $75^{\circ} \mathrm{C}$.

2. Pasteurisasi LTLT (Low Temperature Long Time) yakni pemanasan susu selama durasi waktu 30 menit di suhu $63-66^{\circ} \mathrm{C}$.

3. Pasteurisasi UHT (Ultra High Temperature) yaitu pemanasan susu selama waktu 0,5 detik di suhu $131^{\circ} \mathrm{C}$.

\section{Proses Pendinginan Temperatur Susu}

Proses pendinginan digunakan untuk memperpanjang usia simpan dan mengurangi laju pertumbuhan bakteri pada susu hasil proses pasteurisasi. Mikroorganisme pada suhu dingin tidak dapat berkembang dan tumbuh. Kemasan dari bahan dasar plastik seperti botol atau cup sering digunakan untuk susu fermentasi dan pasteurisasi. Selayaknya kemasan plastik terhindar dari suhu panas dan minyak [5].

\section{Sistem Pendinginan Mesin}

Pembakaran campuran bahan bakar-udara yang terjadi di silinder mesin dapat mencapai temperatur $2.200^{\circ} \mathrm{C}$ atau lebih sehingga seluruh bagian mesin akan menjadi panas. Sistem pendingin merupakan komponen paling penting pada mesin.

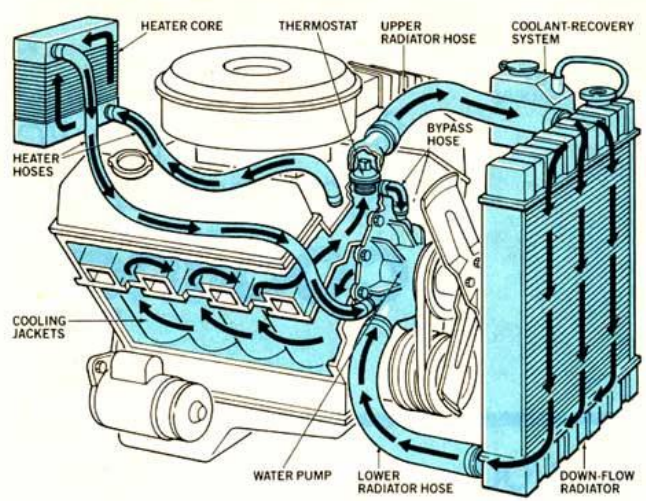

Gambar 2. Sistem Pendinginan Mesin

Metode pendinginan mesin ada dua macam: 
a. Proses pendinginan menggunakan air pada mesin (water cooling system) bekerja dengan cara mengarahkan air melewati mesin agar menyerap panas dan membawanya menuju radiator untuk didinginkan, seperti pada Gambar 2. Kebanyakan mobil menggunakan pendinginan dengan air [6].

b. Pendinginan udara langsung (air cooling system) adalah cara mendinginkan mesin menggunakan sirip-sirip pada bagian blok silinder. Panas yang ditimbulkan oleh mesin disalurkan ke sirip-sirip dan didinginkan oleh udara luar.

Bagian dan Fungsi Sistem Pendinginan dengan air:

a. Selubung air (water jacket)

b. Pompa air

c. Termostat

d. Radiator

e. Kipas angin (fan)

\section{Arduino}

Pada Gambar 3, Arduino Board memiliki lisensi yang bersifat open-source yang berarti bisa digunakan oleh siapapun. Arduino sering kali dipakai untuk eksperimen pada bidang elektronika. Arduino IDE ialah perangkat lunak yang digunakan untuk mengunggah program ke dalam Arduino. Berbagai modul tersedia untuk mikrokontroler ini antara lain bluetooth, GPS, Accelerometer, dan sebagainya.

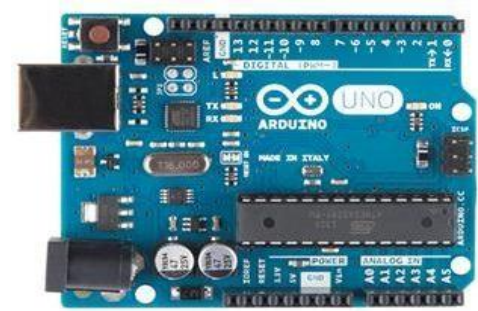

Gambar 3. Arduino Uno R3

\section{Relay}

Pada Gambar 4, relay adalah perangkat yang berfungsi sebagai saklar elektronik dan digunakan untuk mengaktifkan komponen melalui program saat diperlukan. Modul relay tersedia dalam berbagai tegangan kerja yaitu 5 volt DC, 12 volt DC dan 220 volt AC. Terdapat 2 mode input dalam pengaktifan channel modul relay yaitu aktif high (1) dan aktif low (0).

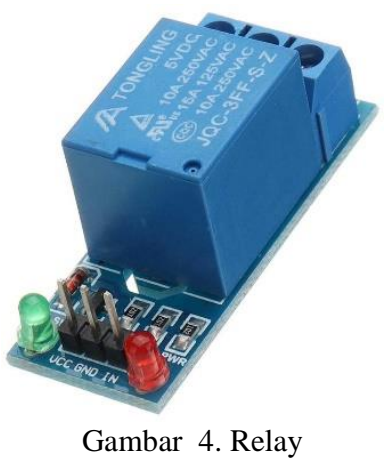

Terdapat 2 jenis Kontak Poin (Contact Point) pada relay yaitu:

a. Kondisi tertutup pada awal sebelum diaktifkan yang disebut Normally Close (NC).

b. Kondisi terbuka pada awal sebelum diaktifkan yang disebut Normally Open (NO).

Komponen dasar relay terdiri dari:

1. Electromagnet (Coil)

2. Armature

3. Saklar penghubung (Contact Point)

4. Pegas

\section{METODE PENELITIAN}

Gambar 5 adalah metode penelitian yang dipakai acuan pengerjaan. Sebelum pembuatan sistem kendali alat pendingin susu dilakukan terlebih dahulu dibuat proses perancangan. Tahap ini dibuat sebagai acuan penyusunan sistem kendali secara lengkap. Berikut adalah diagram blok perencanaan sistem kendali:

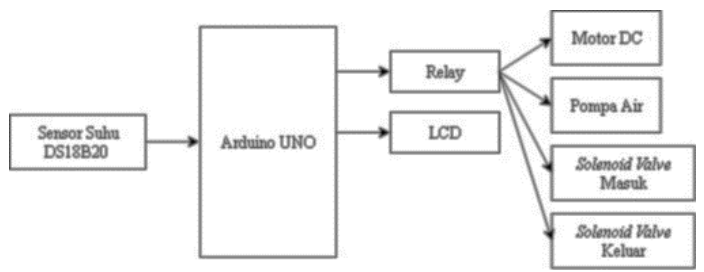

Gambar 5. Blok Diagram Penelitian

Penjelasan setiap bagian diagram akan dijabarkan lebih detail berikut:

1. Input pada Mikrokontroler Input pada Mikrokontroler ini diperoleh melalui Sensor Suhu DS18B20. 
a. Sensor Suhu DS18B20 berfungsi untuk mengambil nilai temperatur dari susu yang akan didinginkan pada bak penampung.

2. Output pada Mikrokontroler

a. Motor DC digunakan sebagai pengaduk susu agar proses pendinginan berlangsung lebih cepat.

b. Aliran air pendingin bersirkulasi dari bak selubung air menuju bak penampung menggunakan Pompa Air.

c. Solenoid Valve Masuk memiliki fungsi untuk mengalirkan susu hasil pasteurisasi ke dalam sistem pendingin.

d. Solenoid Valve Keluar berfungsi untuk mengalirkan susu yang sudah melalui proses pendinginan.

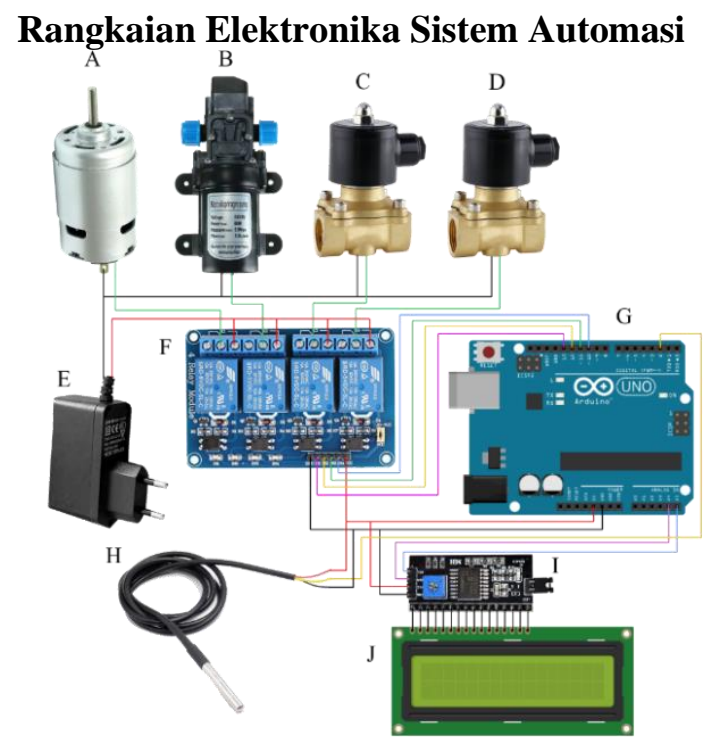

Gambar 6. Rangkaian Elektro Sistem

Pada Gambar 6, dapat dilihat rangkaian sistem kendali yang digunakan pada rancang bangun alat pendingin susu hasil pasteurisasi. Sistem ini menggunakan mikrokontroler Arduino UNO sebagai pusat pengendali. Input di sistem ini berasal dari sensor suhu DS18B20. Sedangkan output-nya terdiri dari Solenoid Valve, LCD, pompa Air, dan Motor Pengaduk.

Daftar nama alat pada Gambar 6 adalah sebagai berikut:

a. Motor DC

b. Pompa Air DC

c. Solenoid Valve Masuk

d. Solenoid Valve Keluar

e. Adaptor 12 Volt
f. Modul Relay
g. Arduino UNO
h. Sensor DS18B20
i. Modul I2C
j. LCD 16x2

\section{Flowchart Keseluruhan Sistem}

Dari flowchart pada Gambar 7, proses pendinginan susu dimulai dengan mengalirkan susu panas melalui kran masuk (valve) ke dalam bak penampung susu dan akan menutup setelah penuh. Sensor suhu yang berada pada bak penampungan susu membaca temperatur dan mengirimkan datanya ke mikrokontroler. Suhu ruangan pada lokasi pembuatan alat ini kurang lebih $32,5^{\circ} \mathrm{C}$. Proses pemanasan susu (High Temperature Short Time) adalah pemanasan cepat (flash) dengan rentang suhu $71-72.5^{\circ} \mathrm{C}$ berdurasi 15 detik dan didinginkan secepat mungkin.

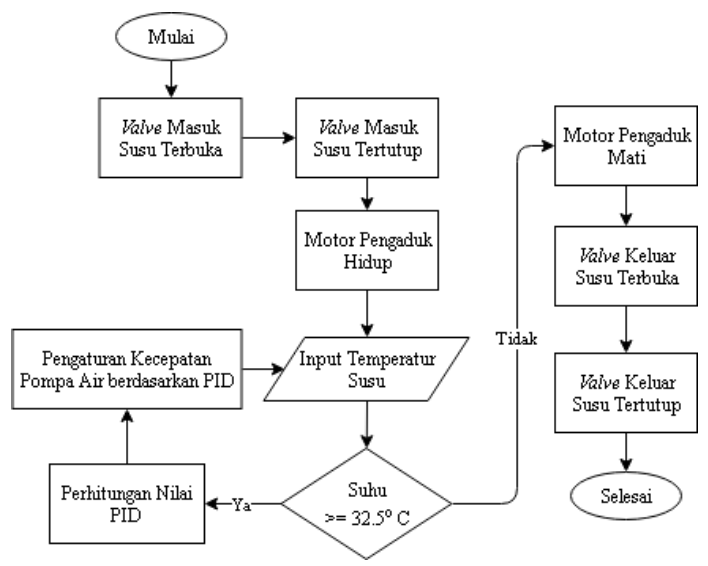

Gambar 7. Flowchart Keseluruhan Sistem

Kontrol PID merupakan kontroler untuk menentukan akurasi suatu sistem instrumentasi yang akan bereaksi terhadap error yang telah diberikan oleh sensor sehingga memberikan nilai perbaikan (feedback) kepada nilai output yang berupa PWM (Pulse Width Modulation). Salah satu teknik modulasi yang mengubah duty cycle dengan nilai frekuensi dan amplitudo tetap ialah PWM. Duty cycle ialah permodelan dari keadaan logika high pada suatu periode sinyal dan disebutkan dalam kondisi persen dari $0 \%$ sampai $100 \%$. Kecepatan pompa dalam mengalirkan air pendingin bergantung dengan kondisi suhu pada bak penampungan susu. Apabila suhu pada bak penampungan susu sudah sesuai dengan temperatur ruangan maka pompa air akan otomatis mati dan kran keluar (valve) akan 
membuka dan mengalirkan susu pada proses pengemasan.

\section{PID (Proportional Integral Derivatif)}

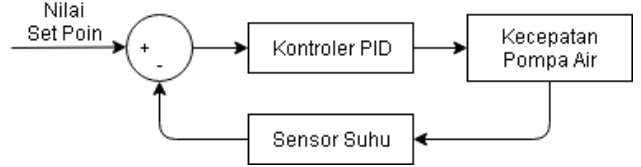

Gambar 8 Blok Diagram Sistem PID

Pada Gambar 8, sistem kendali PID memiliki fungsi untuk mengolah suatu nilai dari sinyal kesalahan atau error. Proses perhitungan nilai error dilakukan dengan menggunakan rumus PID. Nilai error yang dihasilkan dari proses perhitungan digunakan untuk sinyal kendali pada output berupa aktuator. Skema blok diagram PID pada sistem pendinginan suhu dapat dilihat pada Gambar 9.

Sistem yang dibuat memiliki set poin suhu 32.5 derajat celcius. Jika suhu susu tinggi $\left(72^{\circ} \mathrm{C}\right)$ maka kecepatan pompa air akan maksimal, kecepatan tersebut akan berkurang seiring dengan penurunan suhu. Apabila pengukuran suhu telah mencapai set poin sebesar $32.5^{\circ} \mathrm{C}$ maka pompa air akan otomatis mati. Sistem ini menggunakan PID untuk mengontrol kecepatan motor DC agar bekerja lebih baik.

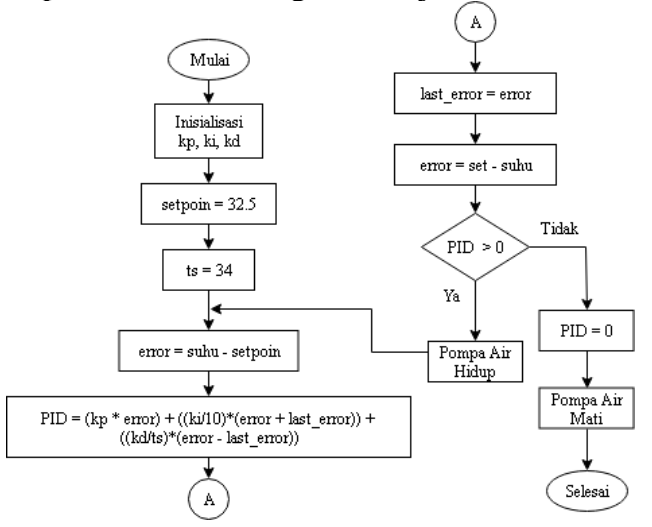

Gambar 9. Flowchart Kontrol PID

Pada Gambar 9, hasil perhitungan nilai error akan disimpan pada variabel error. Nilai error tersebut didapatkan dari pengurangan nilai suhu hasil baca sensor dengan nilai setpoin.

Proses berikutnya adalah penghitungan nilai $\mathrm{P}$ yang didapat dari perkalian nilai $\mathrm{Kp}$ dan error. Nilai I didapat dari perkalian nilai Ki dengan selisih nilai error lama dikurangi nilai error yang baru. Nilai D didapatkan dari pembagian nilai $\mathrm{Kd}$ oleh Ts, kemudian hasilnya dikali dengan selisih nilai error lama dikurangi nilai error yang baru. Semua nilai dari perhitungan tadi akan dijumlahkan menjadi satu. Hasil nilai tersebut akan menjadi acuan hidup matinya motor DC pada pompa air.

\section{Mencari Nilai Kp, Ki, dan Kd}

Pada Tabel 1, tunning kontrol PID berfungsi untuk menentukan nilai paramater aksi dari kontrol Proportional, Integratif, dan Derivatif. Cara mendapatkan nilai melalui metode trial and error.

Tabel 1. Hasil Pengujian Nilai PID

\begin{tabular}{cccc}
\hline Nilai Kp & Nilai Ki & Nilai Kd & Nilai PID \\
\hline 1 & 2 & 1 & 45 \\
3 & 1 & 2 & 120 \\
3 & 2 & 1 & 127 \\
2 & 1 & 3 & 82 \\
3 & 3 & 1 & 135 \\
4 & 3 & 1 & 172 \\
5 & 3 & 1 & 210 \\
3 & 4 & 1 & 142 \\
5 & 4 & 1 & 217 \\
6 & 4 & 1 & 255 \\
\hline
\end{tabular}

\section{Perancangan Mekanik Alat}

Sebelum proses pembuatan lebih dulu dilakukan proses perancangan. Gambar 10 menunjukkan hasil perancangan mekanik.

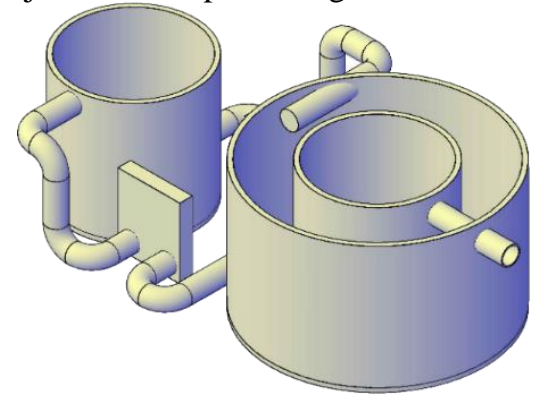

Gambar 10. Desain Alat Pendingin Susu

Proses pembuatan alat merujuk kepada proses perancangan yang dibuat sebelumnya. Hasil pembuatan alat pendingin ditunjukkan pada Gambar 11. 


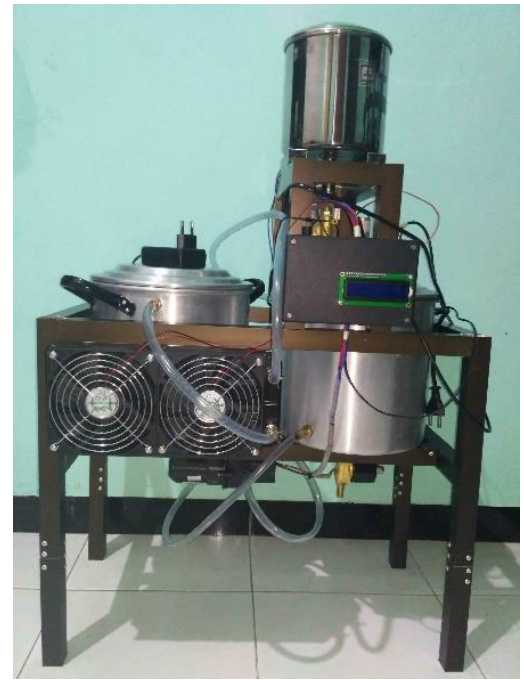

Gambar 11 Rancang Bangun Alat Pendingin Susu

\section{Hasil Pengujian dan Pengamatan}

Pengujian keakuratan sensor suhu DS18B20 dengan membandingkan dengan hasil pengukuran termometer digital.

Tabel 2. Hasil Percobaan Sensor Suhu DS18B20

\begin{tabular}{cccc}
\hline \multirow{2}{*}{ Pengujian } & $\begin{array}{c}\text { Sensor } \\
\text { DS18B20 }\end{array}$ & $\begin{array}{c}\text { Termometer } \\
\text { Digital }\end{array}$ & Selisih \\
\hline 1 & 33.00 & 32.59 & -0.41 \\
2 & 33.30 & 33.30 & 0.00 \\
3 & 38.25 & 39.70 & 1.45 \\
4 & 43.75 & 45.00 & 1.25 \\
5 & 50.44 & 51.20 & 0.76 \\
6 & 54.03 & 55.60 & 1.57 \\
7 & 58.59 & 60.50 & 1.91 \\
8 & 64.56 & 65.20 & 0.64 \\
9 & 71.25 & 72.50 & 1.25 \\
10 & 72.31 & 73.70 & 1.39 \\
\hline Rata - Rata & \multicolumn{3}{c}{0.98} \\
\hline \multicolumn{2}{c}{ Pengujian sensor suhu DS18B20 dengan }
\end{tabular}

Pengujian sensor suhu DS18B20 dengan termometer digital menghasilkan data rata-rata selisih suhu $0.98^{\circ} \mathrm{C}$.

\section{Pengujian Sistem}

Pengujian dilakukan untuk mencari data durasi pendinginan susu tanpa mendapatkan perlakuan apapun. Data suhu diambil menggunakan termometer digital. Volume susu yang digunakan dalam pengujian adalah 1 liter. Pengujian menggunakan panci tertutup dan dibiarkan begitu saja sampai suhu pada termometer yang dicelupkan pada panci menunjukkan suhu ruangan sekitar yaitu $32.5^{\circ} \mathrm{C}$.

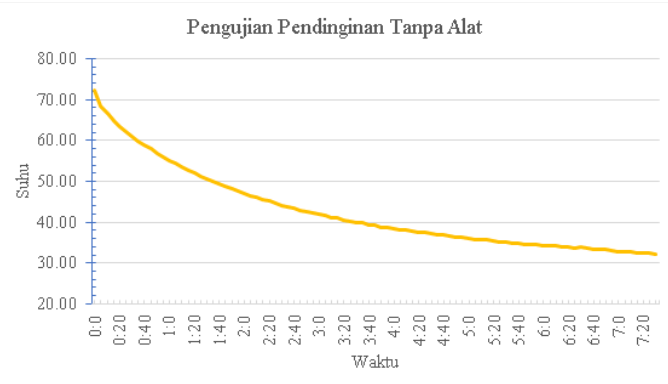

Gambar 12. Pengujian Pendinginan Tanpa Alat

Pada Gambar 12, lama waktu yang dibutuhkan untuk proses pendinginan susu sampai sesuai dengan temperatur ruangan $32.5^{\circ} \mathrm{C}$ dan tanpa mendapatkan perlakuan apapun adalah 7 jam 20 menit.

Tahap pengujian selanjutnya adalah pendinginan menggunakan alat pendingin tanpa penerapan metode PID.

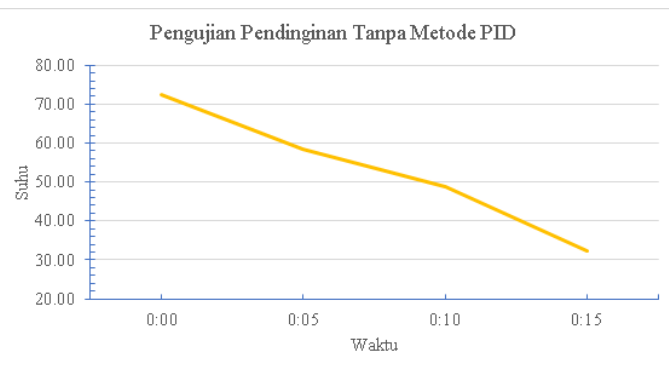

Gambar 13. Pendinginan Tanpa Metode PID

Pada Gambar 13, waktu pendinginan diambil dari mulai berjalannya proses pendinginan sampai suhu susu sama dengan suhu air pendingin. Lama waktu yang dibutuhkan untuk proses pendinginan susu sampai sesuai dengan temperatur ruangan $32.5^{\circ} \mathrm{C}$ adalah 15 menit. Proses pendinginan tanpa menggunakan metode PID memiliki durasi lebih singkat. Namun hal ini berdampak pada kenaikan suhu air pendingin lebih cepat, karena proses pendinginan tidak diatur tanpa perhitungan apapun, sehingga air pendingin hanya dapat digunakan dalam sekali pakai dan selanjutnya dibuang.

Tahap pengujian terakhir adalah pendinginan menggunakan alat pendingin dengan menerapkan metode PID. 


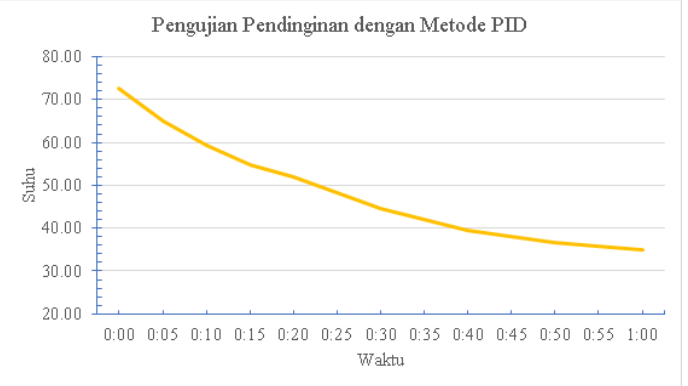

Gambar 14. Pendinginan dengan Metode PID

Pada Gambar 14, lama waktu yang dibutuhkan untuk proses pendinginan susu sampai sesuai dengan temperatur ruangan $32.5^{\circ} \mathrm{C}$ adalah 1 jam 25 menit. Pada proses pendinginan ini, air pendingin dialirkan dari bawah ke atas. Pendinginan yang dilakukan menggunakan alat lebih cepat daripada pendinginan manual, dengan selisih waktu 5 jam 55 menit.

Perbandingan data pada beberapa proses pengujian dapat dilihat pada Gambar 15.

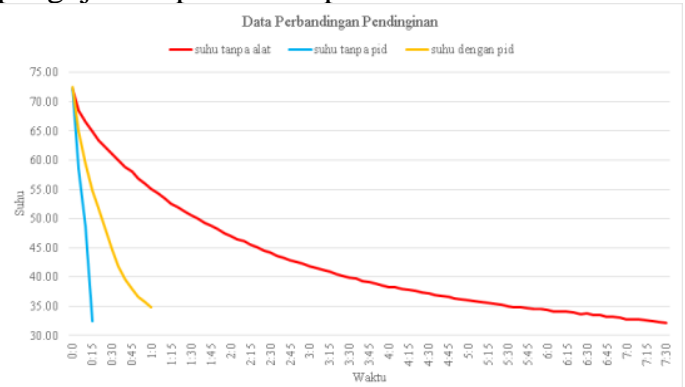

Gambar 15. Perbandingan Proses Pengujian Pendinginan

Pada Gambar 15 menunjukkan perbandingan data hasil pengujian. Dari data tersebut dapat dilihat bahwa proses pendinginan menggunakan alat menjadi lebih cepat.

\section{KESIMPULAN}

Berdasarkan serangkaian pengujian pada sistem yang dibuat dalam tugas akhir ini, terdapat beberapa kesimpulan dan saran yang diperoleh.

1. Penerapan otomatisasi sistem pendinginan susu hasil pasteurisasi menggunakan mikrokontroler Arduino UNO sebagai pusat kendali berjalan dengan baik.

2. Solenoid valve berfungsi dengan baik, volume susu yang mengalir pada bak pendingin sesuai dengan ketentuan.
Solenoid valve bekerja dengan baik saat dijalankan oleh program pada sistem.

3. Proses pendinginan susu tanpa mendapatkan perlakuan apapun dari suhu $72^{\circ} \mathrm{C}$ sampai dengan temperatur ruangan $32.5^{\circ} \mathrm{C}$ adalah 7 jam 20 menit.

4. Rata-rata waktu yang dibutuhkan untuk proses pendinginan menggunakan aliran air pendingin dari bawah ke atas dengan Metode PID adalah 1 jam 25 menit.

5. Pendinginan yang dilakukan menggunakan alat lebih cepat daripada pendinginan manual pada wadah tertutup. Selisih waktu pendinginan manual dengan pendinginan menggunakan alat adalah 5 jam 55 menit.

6. Menurut hasil pengujian selanjutnya, ratarata waktu yang dibutuhkan untuk proses pendinginan menggunakan aliran air dari bawah ke atas tanpa Metode PID menurut hasil pengujian adalah 15 menit.

7. Proses pendinginan tanpa menggunakan metode PID memiliki durasi lebih singkat daripada pengujian yang lainnya tetapi berdampak pada kenaikan suhu air pendingin lebih cepat.

\section{SARAN}

Saran untuk pengembangan alat di penelitian selanjutnya yaitu:

1. Penggantian solenoid valve yang lebih besar agar mempercepat perpindahan aliran susu.

2. Penambahan sensor suhu pada bak air pendingin agar mudah mengetahui kapan saatnya diganti.

3. Penambahan sistem penguras air pada bak air pendingin yang lebih mudah.

4. Pembuatan sistem pengemasan dari hasil pendinginan sistem ini.

5. Menambahkan tombol untuk mengulang otomatis proses pendinginan susu.

\section{DAFTAR PUSTAKA}

[1] Soesatyo, B. 2018. Generasi Milenial dan Era Industri 4.0. https://news.detik.com/kolom/3981811/ge nerasi-milenial-dan-era-industri-40. Diakses pada tanggal 27 Desember 2018. 
Gita Adi, dkk /Journal of Technology and Informatics (JoTI) Vol.1, No.1, Oktober 2019, 41-48

[2] Bachtiar, PAP. 2018. Kendali Temperatur Menggunakan PID Untuk Sistem Pasteurisasi Susu. JCONES (2018).

[3] Nikiuluw, R. 2018. Kendali Suhu Menggunakan Fuzzy Logic Untuk Sistem Pasteurisasi Susu. JCONES (2018).

[4] Wardana, A.S. 2012. Teknologi Pengolahan Susu. Fakultas Teknologi Pertanian. Universitas Slamet Riyadi. Surakarta.

[5] Murti, T.W., H. Purnomo dan S. Usmiati. 2009. Pascapanen Dan Teknologi Pengolahan Susu. Balai Besar Litbang Pascapanen Pertanian, Bogor. Hlm 259599.

[6] Darmawan, I. 2008. Merawat dan Memperbaiki Mobil Bensin. Puspa Swara. Jakarta. 